\title{
Pengenalan Kebudayaan Tradisional melalui Pendidikan Seni Tari pada Anak Usia Dini di BA Aisyiyah Ngadirejo, Sukoharjo
}

Arief Cahyo Utomo ${ }^{1}$, Lisa Widyawati ${ }^{2}$, Rika Supyanti ${ }^{3}$, Nanda Guntur G ${ }^{4}$, Lely Aprillia Arin Dhita ${ }^{5}$, Ayu Rahmadhanti ${ }^{6}$, Ervha Arien Pratama ${ }^{7}$, Akmalia Riskiana ${ }^{8}$, Nadia Yuni Amilia ${ }^{9}$, Muhammad Marwan $\mathrm{P}^{10}$.

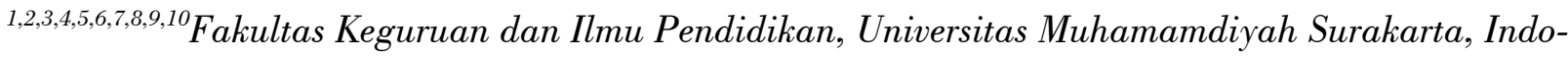
nesia

\section{INFORMASI ARTIKEL}

\section{Histori Artikel:}

Submit: 27 April 2020

Revisi: 2 Mei 2020

Diterima: 4 Mei 2020

Publikasi: 6 Mei 2020

Periode Terbit: Desember 2019

\section{Kata Kunci:}

anak usia dini,

seni tari,

tari semut

\section{Correspondent Author:}

Lisa Widyawati

Fakultas Keguruan dan Ilmu Pendidikan

Universitas Muhammadiyah Surakarta,

Indonesia

Email:sandilisa48@gmail.com

\begin{abstract}
ABSTRAK
Anak usia dini dapat dikatakan sebagai masa keemasan (Golden Age), masa keemasan ini lebih mudah untuk menerima rangsangan positif yang dapat meningkatkan perkembangan kecerdasan yang baik. Media berperan penting memberikan rangsangan positif yang dapat menjadikan anak merasa nyaman dan senang. Salah satu media itu didapat melalui seni tari. Perkembangan kebudayaan saat ini perlu menyesuaikan dengan perkembangan zaman yang semakin maju. Maka dari itu, diperlukan pengenalan kebudayaan sejak dini yang inovatif, kreatif, dan edukatif agar anak-anak memiliki ketertarikan untuk mempelajari kebudayaan. Seni tari memiliki ragam yang sangat banyak, oleh karenanya memilih ragam tari yang memiliki gerakan sederhana namun akan sarat akan makna. Maka dipilihlah Tari Semut dari Jember sebagai pengenalan kebudayaan pada anak usia dini di BA Aisyiyah Ngadirejo. Tari semut memiliki makna untuk memperkenalkan kebudayaan daerah kepada anak, sehingga anak sudah mengenal kebudayaannya sejak dini, kemudian selain itu tujuan pelaksanaan kegiatan untuk membantu mengembangkan rasa percaya diri anak.
\end{abstract}

\section{Pendahuluan}

Perkembangan ilmu pengetahuan dan teknologi saat ini telah berkembang sangat pesat namun tidak diimbangi dengan perkembangan pada kebudayaan,yang berakibat generasi sekarang lebih memilih teknologi cangih seperti gadget dan mulai mengabaikan seni budaya tradisional daerah. Untuk menumbuhkan seni budaya tradisional daerah dapat dilakukan dengan jalan pengalihan nilai-nilai budaya regenerasi ke generasi berikutnya. Regenerasi dapat dimulai pada anak usia dini.
Anak usia dini adalah suatu proses perkembangan seorang individu yang bertujuan membentuk karakter dan pribadi anak (Apriliani, 2017). Anak usia dini dapat dikatakan sebagai masa keemasan (Golden Age), masa keemasan ini lebih mudah untuk menerima rangsangan positif yang dapat meningkatkan perkembangan kecerdasan yang baik. Media berperan penting memberikan rangsangan positif yang dapat menjadikan anak merasa nyaman dan senang. Salah satu media itu didapat melalui seni tari. Arsyad (2011) berpendapat bah- 
wa media adalah pengatar yanga berasal dari kata medius. Penggunaan media dalam pembelajaran PAUD merupakan langkah yang baik untuk pengorientasian atau pengenalan materi yang ada. Dengan media pembelajaran dapat menyampaikan pesan dan maksud guru dalam penyampaian materi. Selain itu media lebih efektif dalam menambah motivasi dan minat belajar siswa sehingga pemahaman nya juga ikut bertambah.

Untuk seni tari Hartono (2012) mengatakan bahwa seni tari merupakan salah satu media pembelajaran yang dapat digunakan untuk mencapai tujuan pembelajaran yang diajarkan. Sehingga seni tari disini bukan gerakan-gerakan tarinya yang dimaksud sebagai tujuan pembelajaran akan tetapi media seni tari ini bertujuan untuk mengenalkan juga tradisi salah satu daerah. Gerakan gerakan dalam media seni tari ini selain bertujuan untuk meningkatkan aktivitas fisik tetapi juga dapat digunakan untuk mengungkapkan ekspresi, ber kreasi sekreatif mungkin dan berapresiasi terhadap seni tari itu sendiri. Sehingga dari kegiatan seni tari tersebut akan didapatkan pengetahuan sekaligus pemahaman yang menjadi tujuan didalam pembelajaran. Akan tetapi dalam media seni tari meskipun tujuan untamanya adalah untuk mencapai tujuan pembelajaran tetap sana dituntut untuk menghafal gerakan-gerakan tari tersebut sehinggan secara tidak langsung akan meningkatkan keterampilan, dan merasakan sentuhan keindahan dalam tari.

Jazuli (2008) mengutarakan bahwa pendidikan seni merupakan pendidikan yang memberikan pengalaman astetik kepada siswa. Pengalaman astetik merupakan pengalaman yang memberikan siswa rasa menghayati semua materi yang ada pada seni tari tersebut seperti halnya nilai keindahan menurut persepsi masing masing. Pemberian pengalaman astetik tersebut berkaitan erat dengan dua kegiatan lainnya yaitu kegiatan apresiasi dan kegiatan berkreasi.

Seni tari dapat menjadi sarana pengenalan kebudayaan sejak dini. Menurut Shomiyatun (2019) pengenalan budaya tradisional ini diharapkan mampu membuat siswa mengetahui budaya yang ada di sekitarnya, menumbuhkan rasa cinta dan menghargai serta mampu melestarikan kebudayaan untuk ke depannya. Perkembangan kebudayaan saat ini perlu menyesuaikan dengan perkembangan zaman yang semakin maju. Maka dari itu, diperlukan pengenalan kebudayaan sejak dini yang inovatif, kreatif, dan edukatif agar anak-anak memiliki ketertarikan untuk mempelajari kebudayaan. Dalam hal ini, sekolah berperan sebagai wadah untuk mengenalkan dan mengajarkan bentukbentuk kebudayaan, salah satunya kebudayaan tradisional. Kebudayaan tradisional yang dimaksud adalah kebudayaan yang tumbuh dari adat istiadat masyarakat setempat. salah satunya seni tari. Seni tari memiliki ragam yang sangat banyak, oleh karenanya peneliti memilih ragam tari yang memiliki gerakan sederhana namun akan sarat akan makna. peneliti memilih Tari Semut dari Jember.

Seni tari dapat menjadi sarana untuk memperkenalkan, membudayakan, dan menanamkan nilai-nilai seni budaya bangsa dan juga dapat melatih keterampilan dan koordinasi gerakan. Utami (2019: 88) menyatakan tari bagi anak usia dini bukanlah sekedar gerakan tanpa makna dan tujuan. Hal ini sejalan dengan pendapat Mulyani (2017: 68) tari anak usia dini adalah gerak tubuh yang menumbuhkan harmoni dan menyelaraskan pikiran untuk mengontrol dan menginterprestasikan tubuh. Karak- 
teristik tari anak usia dini disesuaikan untuk mengembangkan potensi dasar dengan konsep bermain sehingga menarik dan dapat mengekspresikan dirinya secara utuh (Astuti, 2016).

Manfaat tari anak usia dini menurut Haryati (2014) yaitu: 1) aspek kesehatan berkenaan dengan kelenturan gerak badan kemampuan motorik dan kesehatan badan, 2) aspek kecerdasan yaitu melatih berfikir kritis, fleksibel, cepat, dan tepat, 3) aspek psikologis yaitu semangat positif, kreatif, dan mengembangkan kepercayaan diri, 4) aspek sosial yaitu meningkatkan sikap kerja sama, kekompakan, dan penghargaan, 5) aspek estetika yaitu mempertajam kehalusan budi, kepekaan jiwa, dan rasa keindahan.

Secara umum siswa siswa PAUD akan menyenangi pembelajaran yang melakukan berbagai macam aktivitas, karena sifat usia anak PAUD lebih senang bergerak dari pada diam. Anak anak PAUD juga menyenangi apa yang bisa dirasakan langsung seperti melihat dan menirukan gerak sesuai dengan apa yang pernah dilihatnya (Karyati, 2005). Menurut Kamtini dan Tanjung (2005) untuk jenis-jenis tari yang sangat disenangi oleh anak anak usia PAUD adalah seni tari yang yang bersifat riang gembiran terdapat suasana senang dan menyenankan dalam melakukan tarian tersebut geraknya lincah dan sederhana, iringannya pun mudah dipahami. Koreografi atau gerakan gerakan yang ada pada seni tari semut merupakan koreografi yang menggunakan tema kehidupan sehari hari dimana tema kehidupan sehari-hari akan lebih mudah dipahami dan diaplikasikan pada anak karena anak anak lebih terbiasa dengan kehidupan sehari hari dan lebih mudah menirunya atau melakukannya (Hidajat, 2003).
Berdasarkan uraian di atas pengabdian ini bertujuan untuk melihat apakah pembelajaran ini memiliki dampak bagi siswa di BA Aisyiyah Ngadirejo.

\section{Metode Pelaksanaan}

Pengabdian ini dilaksanakan di BA Aisyiyah Ngadirejo, Watubonang. Tawangsari selama kurang lebih 45 hari, yaitu pada tanggal 21 Januari sampai dengan 3 Maret 2020 dengan sampel siswa sejumlah 30 anak. Pengabdian ini bermaksud untuk memahami fenomena tentang apa yang dialami oleh subjek misalnya perilaku, persepsi, motivasi, dan lain-lain dengan kata lain dalam bentuk kata-kata dan bahasa apda suatu konteks khusus yang alamiah dan dengan memanfaatkan berbagai metode alamiah.

Kegiatan ini dilakukan dengan diawali observasi dan wawancara sebagai dasar untuk melakukan program pengabdian ini.

\section{Hasil Pelaksanaan dan Pembahasan}

Sekolah Bustanul Athfal (BA) Aisyiyah Ngadirejo terletak di Dusun Ngadirejo, Kelurahan Watubonang, Kecamatan Tawangsari, Kabupaten Sukoharjo, Provinsi Jawa Tengah. Adapun lokasinya satu lingkungan dengan sekolah MIM Ngadirejo yang posisinya berada di sekitar rumah penduduk. BA Aisyiyah Ngadirejo memiliki lahan yang tidak begitu luas dan hanya terdapat 2 ruang kelas $\mathrm{A}$ dan $\mathrm{B}$, dan satu ruang kantor yang bergabung dengan kelas A. Ruangan kelas terbilang sempit di mana kelas A hanya beralaskan tikar saat proses pembelajaran, sedangkan lahan bermain hanya memiliki 4 jenis permainan karena lahan yang tidak terlalu luas. BA Aisyiyah Ngadirejo memiliki 40 siswa dan 3 (tiga) guru. Tiga guru meliputi 2 (dua) guru pendamping dan 1 (satu) guru Kepala 
Sekolah. Pembelajaran di BA Aisyiyah Ngadirejo mengacu pada pendidikan generasi muslim yang setiap harinya sebelum proses pembelajaran dimulai diisi dengan hafalan surat pendek, hadits, dan membaca iqra'.

Program tambahan untuk meningkatkan keterampilan baca tulis siswa BA Aisyiyah Ngadirejo diadakan kegiatan bimbingan belajar tambahan sepulang sekolah pada hari selasa dan jumat selama 90 menit yang langsung diampu oleh guru kelas yaitu Ibu Affifah dan Ibu Wuri. Untuk kegiatan olahraga BA Aisyiyah Ngadirejo biasanya dilaksanakan pada hari Rabu dan Jumat, pada hari Rabu melaksanakan senam di ruangan kelas B, sedangkan hari Jumat dilaksanakan kegiatan jalan sehat berkeliling di sekitar Dusun Ngadirejo.

Selama pelaksanaan KKN-Dik, BA Aisyiyah Ngadirejo mendapatkan tambahan kegiatan tari dari mahasiswa. Hal ini mendapatkan persetujuan dari Kepala BA Aisyiyah Ngadirejo, Ibu Newin. Kurang lebih 45 (empat puluh lima) hari, mahasiswa KKN mendampingi dan melatih kegiatan tari, untuk selanjutnya diharapkan guru pendamping dapat melatih tari secara rutin dan mandiri.

Berdasarkan hasil observasi, wawancara dan dokumentasi yang dilakukan oleh peneliti pelaksanaan kegiatan tari tradisional di BA Aisyiyah Ngadirejo dilakukan setiap hari rabu setelah pelaksanaan senam. Adapun tarian yang diajarkan adalah tari semut. Tujuan pelaksanaan kegiatan tari semut ini adalah untuk memperkenalkan kebudayaan daerah kepada anak, sehingga anak sudah mengenal kebudayaannya sejak dini, kemudian selain itu tujuan pelaksanaan kegiatan untuk membantu mengembangkan rasa percaya diri anak. Tari semut ini menggunakan musik pengiring yang diambil dari youtube diputar melalui handphone yang dihubungkan dengan speaker. Kegiatan ini dilaksanakan di ruangan kelas TK B.

Sebelum kegiatan latihan dimulai, mahasiswa KKN-DIK mengumpulkan anak dan merapikan barisan anak agar pelaksanaan kegiatan latihan tari menajdi kondusif. Kegiatan diawali dengan membaca doa dan ice-breaking. Selanjutnya guru berperan sebagai instruktur di mana guru akan memberikan contoh gerakangerakan tari semut ini kepada anak, dan anak akan mengikuti gerakan yang dicontohkan oleh instruktur. Kegiatan ini dilakukan berulangulang sampai menjelang waktu istirahat. Kegiatan ini ditutup dengan membaca doa bersama. Kendala dalam pelaksanaan kegiatan Tari Semut itu sendiri terdapat pada anak yaitu kadang anak merasa bosan karena tarian dilakukan berulang-ulang yang mengakibatkan tidak bersemangat dalam mengikuti kegiatan tari tersebut. Selain itu banyaknya anak tidak sebanding dengan ukuran kelas B.

Berdasarkan data dari hasil pengabdian yang dilakukan di BA Aisyiyah Ngadirejo. Pertama tahap-tahap pelaksanaan kegiatan meliputi menyiapkan media yang dibutuhkan yaitu pengeras suara, menyiapkan anak-anak untuk berbaris mengawali dan mengakhiri kegiatan dengan membaca doa.

Pelaksanaan kegiatan tari dilakukan sebanyak satu kali dalam seminggu yaitu pada hari Rabu, tujuan pelaksanaan kegiatan tari di BA Aisyiyah Ngadirejo untuk memperkenalan sejak dini keanekaragaman kebudayaan Indonesia lewat tari tradisional. Kegiatan tersebut diharapkan juga dapat membantu perkembangan motorik anak dan rasa percaya diri anak.

Dalam pelaksanaan kegiatan tari ini, peneiliti mengharapkan kesadaran siswa akan 
pentingnya menghargai budaya yang dimiliki Negara Indonesia. Pengenalan ragam budaya secara tidak langsung sehingga tidak membosankan. Sesuai dengan kurikulum Pendidikan Anak Usia Dini yang lebih mengedepankan belajar mengeskplorasi, sehingga lebih banyak melakukan gerakan fisik dibandingkan hanya dengan teori. Untuk pelaksanaan kegiatan tari ini, tidak ada pemaksaan bagi siswa, lebih ditujukan agar para siswa merasa senang mengikuti kegiatan ini. Sistem yang digunakan adalah belajar sambil bermain. Sehingga kedepannya, siswa tertarik lebih jauh untuk mempelajari kebudayaan yang ada. Kemudian dapat dilanjutkan ketika melanjutkan di jenjang sekolah yang lebih tinggi. Dengan mengajarkan kebudayaan sejak dini semoga kedepannya tumbuh generasi muda yang cinta akan kebudayaan negerinya dan melestarikannya.

Kendala yang dihadapi ketika pelaksanaan kegiatan tari ini adalah (1) rumitnya pengondisian anak untuk mempersiapkan diri. Untuk memulai kegiatan tari diperlukan waktu yang lumayan lama. Hal ini dikarenakan memunculkan mood anak agar dapat berlatih tari diperlukan siasat dan teknik yang berbedabeda pada setiap anak. Oleh karena itu, perlunya pendampingan dan motivasi sebelum pelaksanaan kegiatan tari ini. (2) Tempat latihan yang kurang luas sehingga kurang kondusif dalam pelaksanaan kegiatan, hal ini karena ketika pelaksanaan kegiatan tari, sebagaian anak menari, sebagain anak belajar, sehingga anak-anak pun kurang fokus. (3) Alat pengeras suara yang kurang memadai, dalam hal ini pengeras suara yang digunakan masih kalah dengan suara anak-anak.

Cara mengatasi kendala dalam pelaksanaan kegiatan tari tersebut dengan beberapa cara seperti pelatih memberikan motivasi membujuk agar kembali mau mengikuti gerakan yang diajarkan pelatih. Untuk masalah tempat yang kecil dilakukan pembagian kelompok tari menjadi beberapa kelompok.

Pelaksanaan pementasan kegiatan Tari Semut, pertama kali dilaksanakan ketika acara parenting yang dilaksanakan pada tanggal 27 Februari 2020. Untuk kostum, terinspirasi dari bentuk semut yang bewarna hitam ditambah dengan pernak-pernik warna kuning.

\section{Simpulan}

Berdasarkan hasil wawancara, observasi, dan dokumentasi di BA Aisyiyah Ngadirejo kegiatan Tari Semut yang diharapkan untuk mengembangkan pengetahuan dan memperkenalkan keanekaragaman kebudayaan Indonesia lewat tari diawali dengan doa dan Ice Breaking. Tari semut ini menggunakan musik pengiring yang diambil dari youtube diputar melalui handphone yang dihubungkan dengan speaker. Guru akan memberikan contoh gerakan-gerakan tari semut ini kepada anak, dan anak akan mengikuti gerakan yang dicontohkan oleh instruktur. Kegiatan ini dilakukan berulang-ulang sampai menjelang waktu istirahat. Kegiatan ini ditutup dengan membaca doa bersama.

Bagi guru sebaiknya kegiatan tidak dilakukan hanya satu minggu satu kali, tetapi 2 sampai tiga kali dalam satu minggu dan sebaiknya menjelaskan dari mana tarian itu berasal, makna tarian tersebut, tujuan menarikan tarian tersebut, sehingga tercapai tujuan utama memperkenalkan kebudayaan Indonesia lewat tari. Untuk cara mengajar tarian sebaiknya guru memberikan media yang menarik sehingga siswa termotivasi dan tidak mudah bosan mengikuti gerakan tari. 


\section{Daftar Pustaka}

Apriani, A. (2017). Penerapan Tari Kreatif Dengan Eksplorasi Imagery Lingkungan Hidup Anak Usia Dini. Early Childhood: Jurnal Pendidikan,1(2),64-75. https://doi.org/10.35568/earlychildho od.vli2.118

Arsyad, A. 2011. Media Pembelajaran. Jakarta: PT Rajagrafindo Persada.

Hartono. 2012. Pembelajaran Tari Anak Usia Dini. Semarang: Unnes Press.

Hidajat, Robby. 2003. Koreografi Anak. Malang: Balai Kajian Seni dan Desain Fakultas Sastra Universitas Negeri Malang

Jazuli, M. 2008. Paradigma Kontekstual Pendidikan Seni. Surabaya: Unesa University Press. Jurnal Pendidikan Modern, $5(1)$, $22-31$. https://doi.org/10.37471/jpm.v5il.64

Kamtini dan Tanjung. (2005). Bermain Gerak dan Lagu di Taman KanakKanak.Jakarta: DIRJEN DIKTI

Karyati, Dewi dkk. 2005. Pengantar Bahan Ajar Pendidikan Seni Tari dan Drama.

Kurniawati, L. D., \& Azizah, E. N. (2019). Analisis Pembelajaran Tari Tradi- sional Penthul Melikan pada Anak Usia 4-6

Kusumastuti, E. (2004). Pendidikan Seni Tari Pada Anak Usia Dini Di Taman Kanak-Kanak Tadika Puri Cabang Erlangga Semarang Sebagai Proses Alih Budaya. V.

Kusumastuti, E. (2016). Pelatihan Pembelajaran Seni Tari Sebagai Proses Alih Budaya Pada Anak Usia Dini Bagi Guru Taman Kanak-kanak Tadika Puri Wilayah Semarang.

Setiawan, A, Saida, N., \& Kurniawati, T. (n.d). Pembelajaran Seni Tari Sebagai Media Mengembangkan PG PAUD FKIP Universitas Muhammadiyah Surabaya. 186192.

Shomiyatun. (2019). Pentingnya Menumbuhkan Kesadaran Budaya Tradisional Pada Anak.1(2), 62-71.

Sutisna, A. (2015). Prosiding Seminar Nasional Pendidikan FKIP. (November) 257269.

Utami, W.T., Yeni I., \& Yaswinda. (2019). Pelaksanaan Kegiatan Ekstrakurikuler Tari Tradisional di Taman Kanak-Kanak Sani Ashila Padang Winda, 4(2) 87-94. 